\title{
DESIGNING PALEMBANG'S TYPICAL CULINARY INFORMATION SYSTEMS BASED ON WEBSITE AND SOCIAL MEDIA
}

\author{
${ }^{1}$ Yudha Wahyu Hidayat, ${ }^{2 *}$ Leon A. Abdillah \\ ${ }^{3}$ Imam Prayuda, ${ }^{4} \mathrm{Ahmad}$ Joko Kusumo, ${ }^{5}$ Desta Uda Pranata, ${ }^{6} \mathrm{M}$. Syarriansyah \\ 1,2,3,4,5,6 Program Studi Sistem Informasi, Fakultas Ilmu Komputer, Universitas Bina Darma, \\ Jl. Ahmad Yani No.3, Palembang \\ ${ }^{*}$ Corresponding Email: leon.abdillah@yahoo.com
}

(Diterima: 10 Maret 2020,direvisi: 2 Mei 2020, disetujui: 5 Mei 2020 )

\begin{abstract}
Information technology has opened up digital economic opportunities in Indonesia. A number of applications of information technology are the internet, websites and social media. The internet has become a medium of data and information traffic with very large capacities and very high speeds. Website can be used as virtual places for various purposes. Social media can be used as an online social media. Small and medium businesses are one of the pillars of national economic growth. But with the existing limitations, the small and medium-sized businesses (SMEs) actors/officers are still constrained by the promotion of their products. All the facilities and advances in information technology need to be packaged in such a way that they can be utilized by SMEs in running their business. This research will design a Palembang culinary information system website. The method used is web engineering which consists of 5 (five) phases: communication, planning, modeling, construction, and dissemination. The results of this study are in the form of web prototype Palembang's culinary information system that can provide information about Palembang's culinary products for social media-based SMEs.
\end{abstract}

Keywords: Online Promotion Media, Palembang's Typical Culinary, Social Media, SMEs Palembang City, Web Engineering.

\begin{abstract}
ABSTRAK
Teknologi informasi telah membuka peluang digital ekonomi di Indonesia. Sejumlah aplikasi dari teknologi informasi adalah internet, website, dan media sosial. Internet telah menjadi media lalu lintas data dan informasi dengan kapasistas yang sangat besar dan kecepatan yang sangat tinggi. Website dapat digunakan sebagai virtual places untuk berbagai kepentingan. Media sosial dapat digunakan sebagai media bersosialisasi secara online. Pelaku usaha kecil dan mengenah merupakan salah satu penopang pertumbuhan perekonomian bangsa. Tetapi dengan keterbatasan yang ada, para pelaku UKM masih terkendala promosi atas produk-produknya. Semua fasilitas dan kemajuan teknologi informasi tersebut perlu dikemas sedemikian rupa agar dapat dimanfaatkan oleh pelaku usaha kecil dan menengah (UKM) dalam menjalankan bisnisnya. Penelitian ini akan merancang website sistem informasi kuliner khas Palembang. Metode yang digunakan adalah web engineering yang terdiri atas 5 (lima) fase: komunikasi, perencanaan, pemodelan, konstruksi, dan penyebaran. Hasil dari penelitian ini berupa purwarupa web sistem informasi kuliner khas Palembang yang dapat memberikan informasi seputar produk kuliner khas Palembang para pelaku UKM berbasis media sosial.
\end{abstract}

Kata Kunci: Media Promosi Online, Kuliner Khas Palembang, Media Sosial, UMKM Kota Palembang, Web Engineering.

\section{INTRODUCTION}

The development of the digital economy in Indonesia is growing rapidly from year to year. This development is due to the growth factor of information technology (IT) which is increasingly entering Indonesia, such as smartphones, laptops, computers and other information technologies. The development of information technology has shifted to the era of mobile and ubiquitous computing [1]. 
This development cannot be separated from policy support from the free market of the Indonesian and world economies. The development of information technology can help the public and entrepreneurs in reaching broad market areas through digital markets from the promotion of products that they do especially on social media.

Social media is one of the most widely used applications in the world. Until January 2020 Facebook still occupies the most widely used social media by the world's population. Even Facebook and Youtube become social media that has been used by 2 (two) billion people in the world. The statistics of social media users appear similar to Figure 1 [2]. Social media was initially used by its users to conduct virtual social interactions such as sharing statuses, photos, activities, and others. Along with the times, social media is also used for business activities. The most commonly used business activity is the promotion [3] of a business or product. Social media can reach a wide range of market areas that can make it easier for SMEs to market and promote products to various regions that can be enjoyed by the wider community. With a broad market reach, it will trigger long distance bookings both directly and online.

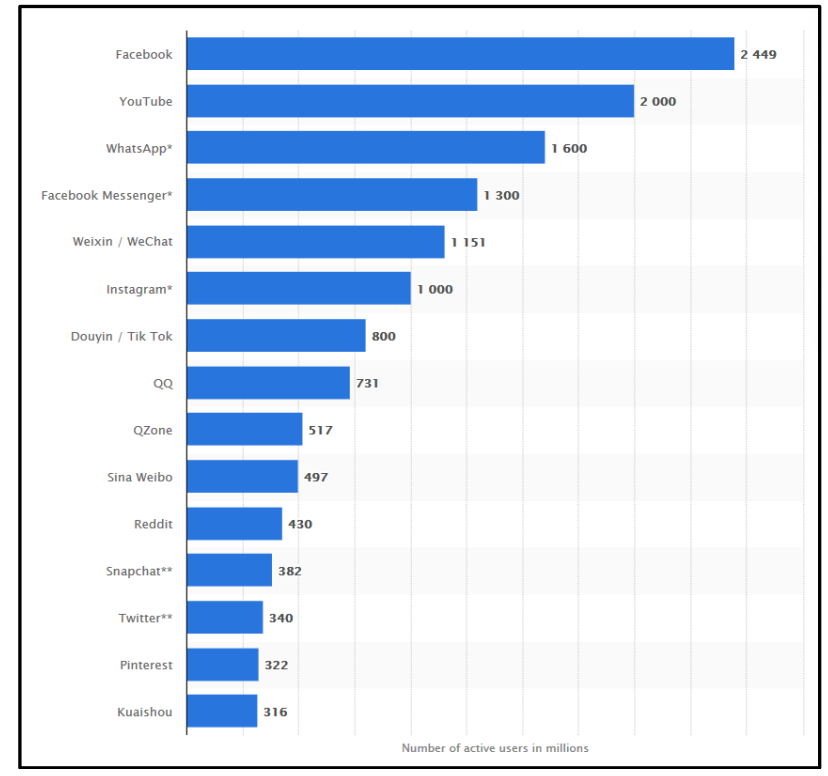

Figure 1 Social media statistics (january 2020)

In Indonesia currently, Small and Medium Enterprises (SMEs) are experiencing rapid growth and the need for promotional media in supporting the process of increasing the sales of goods or services offered by SMEs [4]. This is in line with what is done by several culinary entrepreneurs, especially in the city of Palembang. Palembang's culinary specialties are one of the acculturation foods of various cultures, the city nicknamed "Venice of the East" has produced culinary products that are much in demand by people in Indonesia.

Observations have been made to a number of typical SMEs in Palembang. At present the marketing system of Palembang's typical culinary is still carried out conventionally. Even the majority of Palembang's culinary SMEs rely solely on word of mouth marketing systems. The biggest challenge was when the global pandemic COVID-19 entered Palembang. COVID-19 [5] caused by SARS-CoV-2 [6] has changed many people's activities to be restricted in the context of social distancing or physical distancing [7]. Business activities must find alternative ways to continue operating without violating the COVID-19 preventive health protocol. The biggest challenge was when the global pandemic COVID-19 entered Palembang. COVID-19 caused by SARS-CoV-2 has changed many people's activities to be restricted in the context of social distancing or physical distancing. Business activities must find alternative ways to continue operating without violating the COVID-19 preventive health protocol. The results can be concluded that the lack of media in the process of promoting Palembang's culinary products. Thus, this research will involves social media as modern business locomotive [8] and process [9].

By paying attention to these conditions, it is necessary to design a web media that can accommodate SMEs in promoting their typical Palembang culinary products. The web will be built 
using web engineering [10] consisting of 5 (five) phases: 1) Communication, 2) Planning, 3) Modeling, 4) Construction, and 5) Deployment. With web engineering, the developer will have the ability to understand problems not only from the technology side but also from the business aspect.

The purpose of this study is to design a culinary information system portal in Palembang. The expected benefits from the existence of the portal are to become an online media forum for Palembang SMEs in promoting their typical Palembang culinary products. The scope of this research is 1) information on typical culinary SME shops, 2) A list of Palembang special foods which in the development of this system only focuses on three special foods (fish-cake/pempek), fishcracker/kemplang, and various typical cakes), and 3) social media account information of the owners/officers SMEs.

\section{LITERATURE REVIEW}

In the literature review section, a number of theories and previous studies will be explained which form the basis of designing a culinary web-based culinary information system. This section consists of 3 (three) sub-sections, namely: 1) Social Media and Web-based Promotion, 2) Small Medium Enterprises (SMEs), and 3) Web Engineering.

\subsection{Social Media and Web-based Promotion}

The social media applications enable users not only to produce the information but also to distribute it freely [11]. The classical marketing theory involves promotion and place. Since the existence of social media, promotion and place combined with information technology has opened new opportunities for the promotion of a product. Social media become a hybrid element [12] that able to facilitate customers to customers sharing experience. In a business context, social media presence can provide great benefits [3]. The results of research using the Technological Acceptance Model (TAM) also explained that the use of social media can be well received by SMEs [4]. Social networking helps entrepreneurs in the white elephant country, Thailand, to reduce risk and transaction costs, as well as increase access to business ideas, knowledge, and venture capital [13].

A number of studies with the theme of culinary promotion in Palembang: 1) The utilization of social networking as promotion media for handicraft business in Palembang [3], 2) E-Commerce and packaging innovation for Palembang city pia producers [14], and 3) Application for Empek-Empek Culinary Location Search in Palembang "Pempek Finder" [15]. Those studies are still reviewing 1 (one) type of product only. In this study not only reviews the most popular products of Palembang, Pempek, but also the kemplang and a variety of Palembang specialty cakes. then this study involved a number of SMEs in the city of Palembang

\subsection{Small Medium Enterprises (SMEs)}

One of the economic pillars of a nation is the non-government business world. In Indonesia, the level of business is regulated in the Republic of Indonesia Law No. 20/2008 [16] concerning Micro, Small and Medium Enterprises (MSMEs, SMEs).

Table 1 MSMEs \& SMEs Criteria

\begin{tabular}{llll}
\hline No & Business Level & Most net worth (million) & Most annual sales (million) \\
\hline 1. & Micro business & Rp50 & Rp300 \\
\cline { 2 - 4 } 2. & Small business & $>$ Rp50 - Rp500 & $>$ Rp300 - Rp2.500 \\
\cline { 2 - 4 } 3. & Medium business & $>$ Rp500 - Rp10.000 & $>$ Rp2.500 - Rp50.000 \\
\cline { 2 - 4 } 4. & Big business & $>$ Rp10.000 & $>$ Rp50.000 \\
\hline
\end{tabular}

While the small and medium business category in Thailand is divided into at least 3 (three) sectors [13]: 1) Production sectors (agriculture, manufacturing, and mining), 2) The trade sector (wholesale and retail), and 3) Service sector. 


\subsection{Web Engineering}

The web engineering approach is used to develop a WebApp consisting of 4 (four) increments. Each increment will apply the 5 (five) web engineering [10] phases. Those 5 (five) phases are:

1) Communication (Formulation, Negotiation, Elicitation)

2) Planning (Estimation, Risk Analysis, Scheduling, Monitoring)

3) Modeling (Analysis, Design)

4) Construction (Coding, Testing)

5) Deployment (Delivery, Evaluation)

\section{RESEARCH METHODS}

This research method uses existing processes in the web engineering framework. The contents of this section will review the activities that exist in each phase of web engineering. An overview of the web engineering framework can be seen in figure 2 .

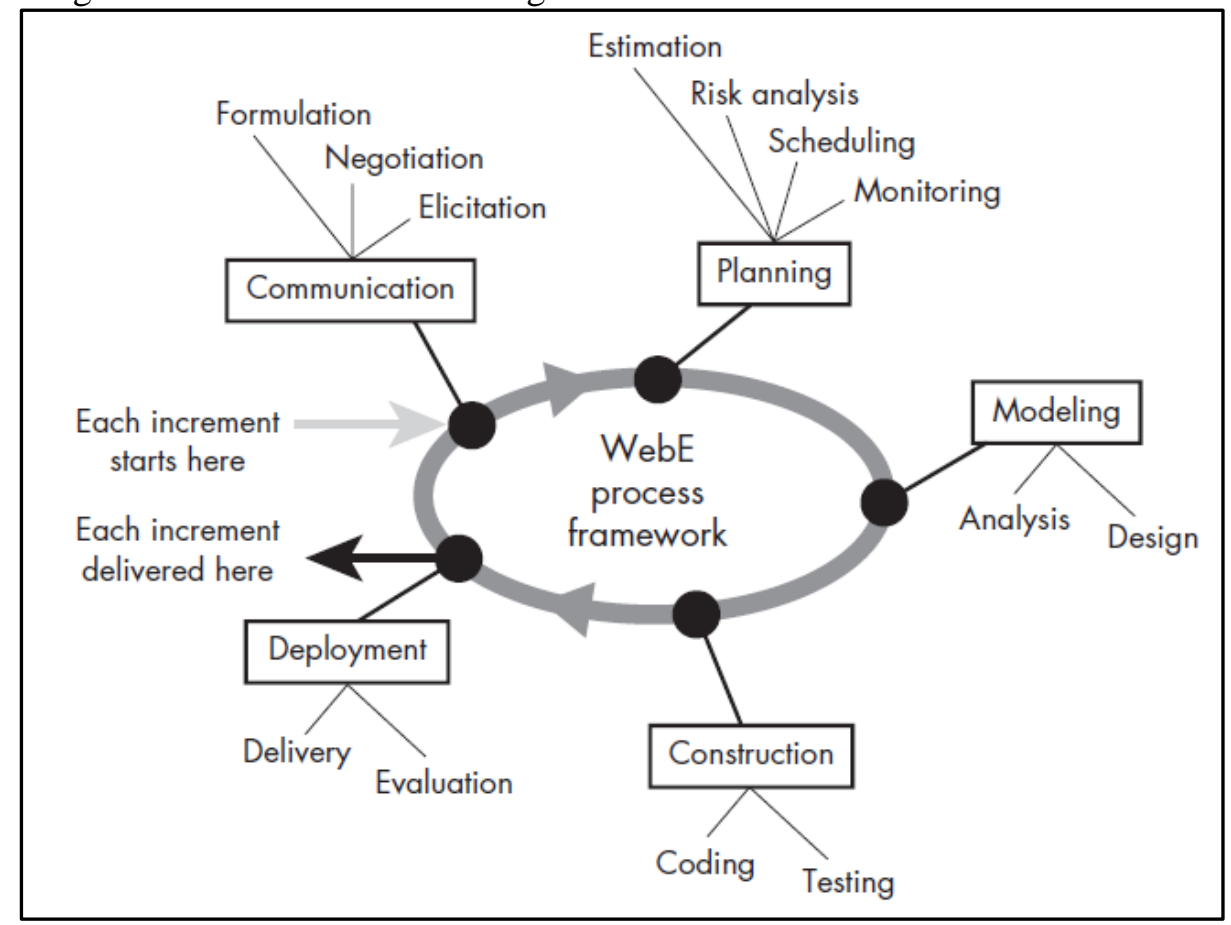

Figure 2 Web engineering process framework

\subsection{Communication}

The initial phase of web engineering is communication which consists of 3 (three) sub-activities, namely: 1) Formulation, 2) Negotiation, and 3) Elicitation. At this stage, the formulation of the system development goals is determined based on the limitations in the system contained in the project planning documentation report in progress one. The formulation activities are activities to formulate what kind of services are needed by SMEs actors and officers with the existing limitations.

The communication phase produces a number of inputs for the system to be developed, such as: 1) The system can display information about Palembang's culinary products along with product information, 2) The system can display a list of Palembang's culinary MSME shops along with store information such as social media accounts, addresses and others, 3) The system can filter Palembang's culinary products based on the highest and lowest prices, and 4) The system can search culinary products.

\subsection{Planning}

The second phase of web engineering is planning which consists of 4 (four) sub-activities, namely: 1) Estimation, 2) Risk Analysis, 3) Scheduling, and 4) Monitoring. This stage aims to calculate the estimated cost of the system making project, the estimated amount and time of system 
development, evaluation of project development risk and the definition of the development schedule for the next version (if needed).

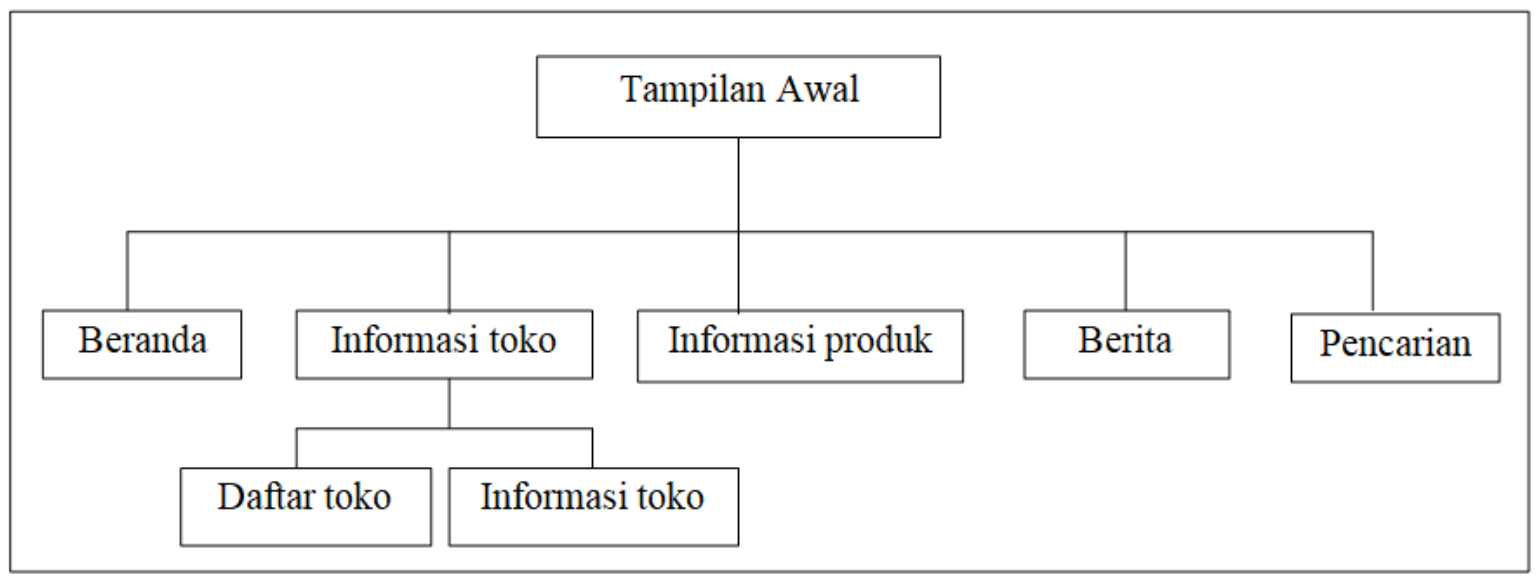

Figure 3 Plan for the design of palembang's typical culinary system hierarchy module

\subsection{Modeling}

The third phase of web engineering is planning. This phase consists of 2 (two) activities, namely: 1) analysis, and 2) design. At this stage an activity occurs to determine the technical requirements and identification of information that will be displayed in the system that will be included in the elements of the design specification documentation. This phase also explains database design [17] and modeling using the Unified Modeling Language (UML) [18]-[20].

In the development of system design there are several tables in the database [21], [22]. In this section describes the relationship between these tables which is illustrated through UML class diagrams (see Figure 4).

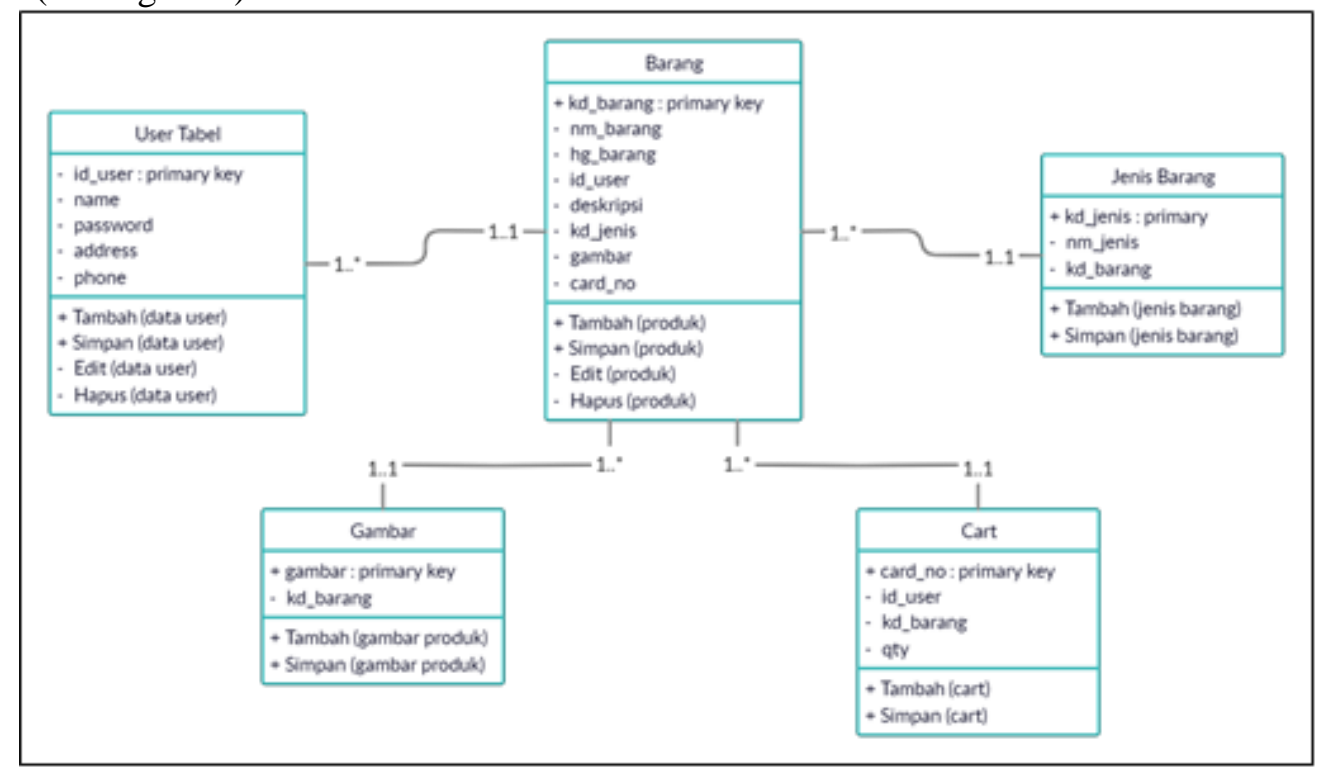

Figure 4 Plan for the design of palembang's typical culinary system hierarchy module

\subsection{Construction}

The fourth phase of web engineering is construction. This phase consists of 2 (two) activities, namely: 1) coding, and 2) testing. In this phase, the design is translated into the programming language used. Then the program will be tested to suit the needs and desires. Web development uses a number of facilities available on the WordPress CMS [23]. Wordpress itself is a platform for blogs that are very popular and easy to use [24]. Utilization of Wordpress CMS is easier to use and cheaper to maintain compared to having to be developed by building a cloud technology-based system [25]. 


\subsection{Deployment}

The fifth phase of web engineering is employment. This phase consists of 2 (two) activities, namely: 1) delivery, and 2) evaluation. In this phase, the tested program (with databases) will be sent to the users. Once the users understand how to use or operate the WebApp, users will be asked to do an evaluation.

\section{RESULTS AND DISCUSSION}

In the results section and discussion will present the results of the design in the form of a prototype culinary information system website typical of Palembang. Each display of results will be followed by a discussion that corresponds to the topic of this study.

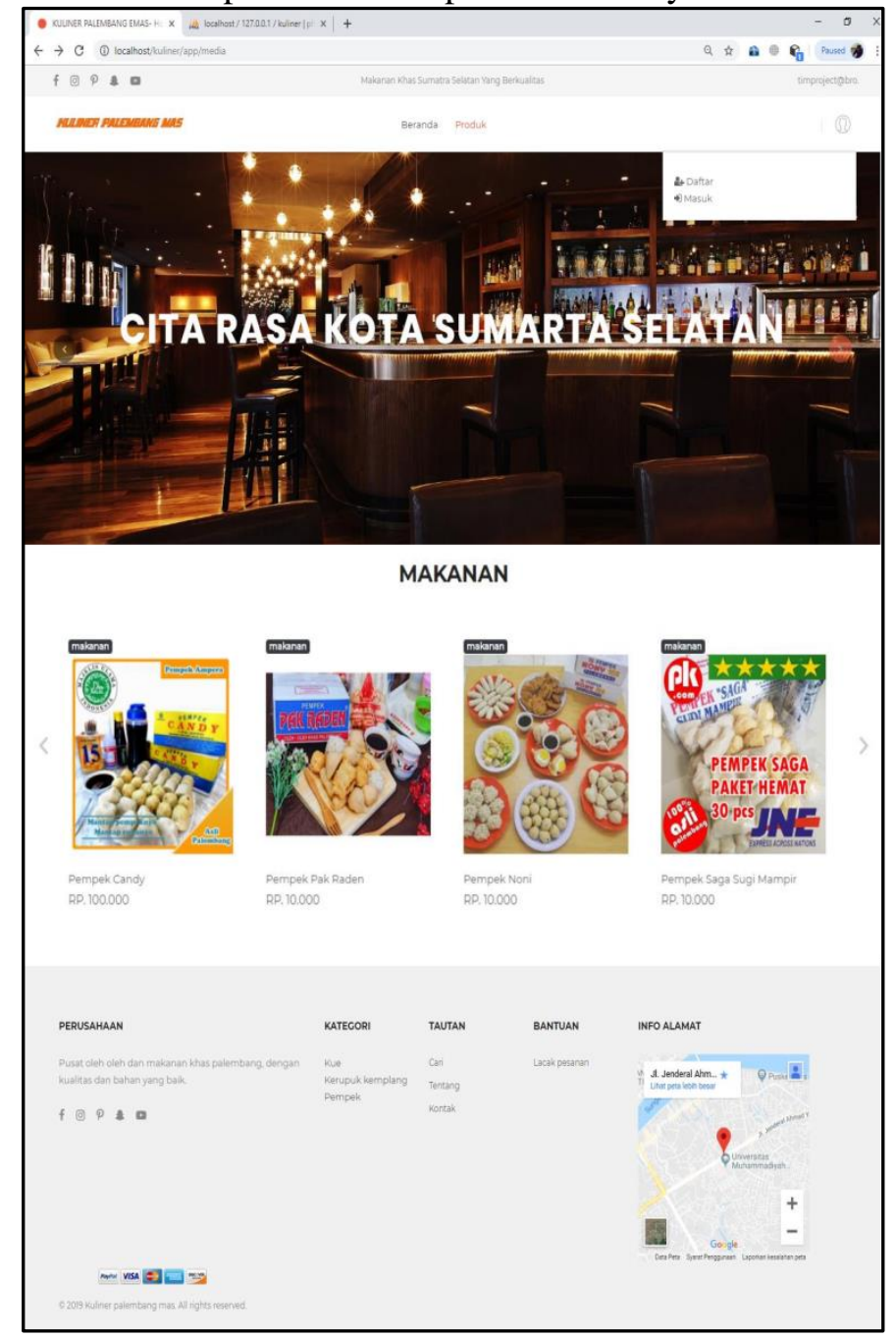

Figure 5 Website main Menu

\subsection{Website Main Menu with Easy Navigation}

The main menu display of this website can be used by users or guests to search for shops and culinary products typical of Palembang (Figure 3). In this menu, the user or guest can view the product menu and filter the desired product according to the highest or lowest price provisions and can adjust the product based on food categories namely pempek, kemplang and various cakes typical of Palembang.

At the top of the website a header, homepage, product, and login are displayed (Figure 5). Product search features and typical Palembang culinary shops can be done in this menu, users only need to enter the product search keywords in the search field then the data searched will appear in search results. 
Menu navigation is very simple so it's easy to use. Visitors or potential customers can directly click on the image to see detailed information.

\subsection{Product Menu Update}

In this menu the user or guest can see information on the store and various products in the system. There are several features in this menu, namely the food category and the lowest and highest price filters and a search feature that can be used to search for products or culinary shops.

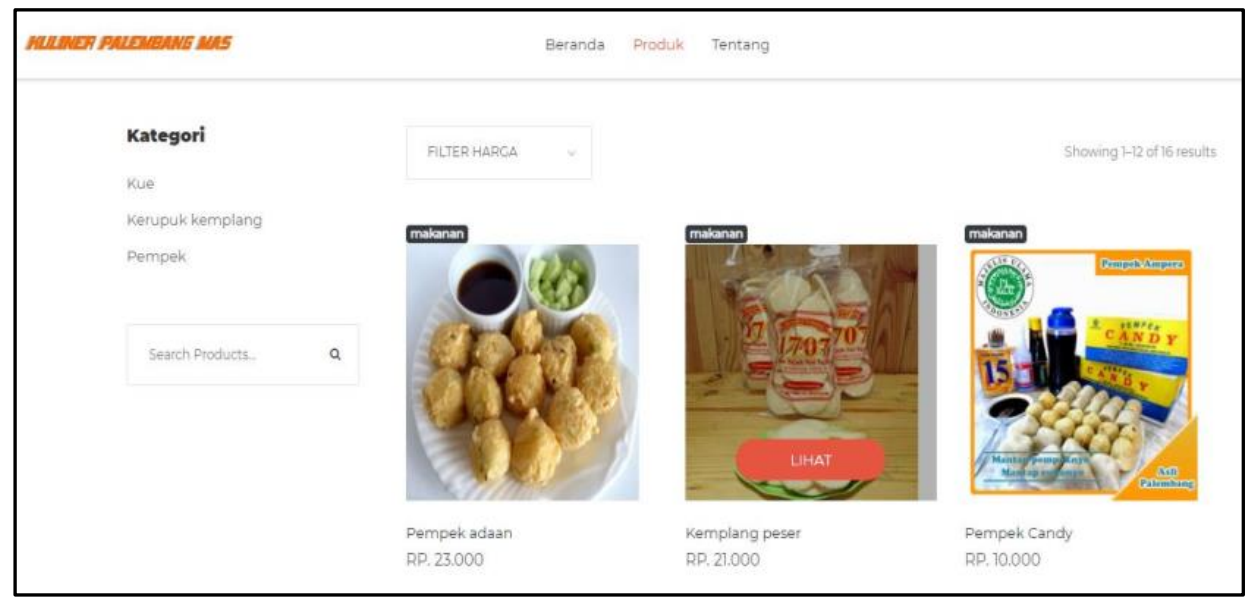

Figure 6 Product menu

By providing access facilities to the admin of each store, the store will easily update their products and services. Store admins can update new products, promotions, change the shop food icon, as well as other info (e.g. WhatsApp number, new social media accounts, etc.)

\subsection{Product View Menu Attractiveness}

Users or guests while in the product menu can choose various products to view detailed product information. The following figure shows the results of the product detail menu display design. Detailed information of a product is displayed separately. In addition to the product name also comes with a store name, facebook address, WhatsApp number, etc.

In order to attract the interest of visitors or potential customers, each product will be equipped with attractive images and detailed information in the right hand panel.

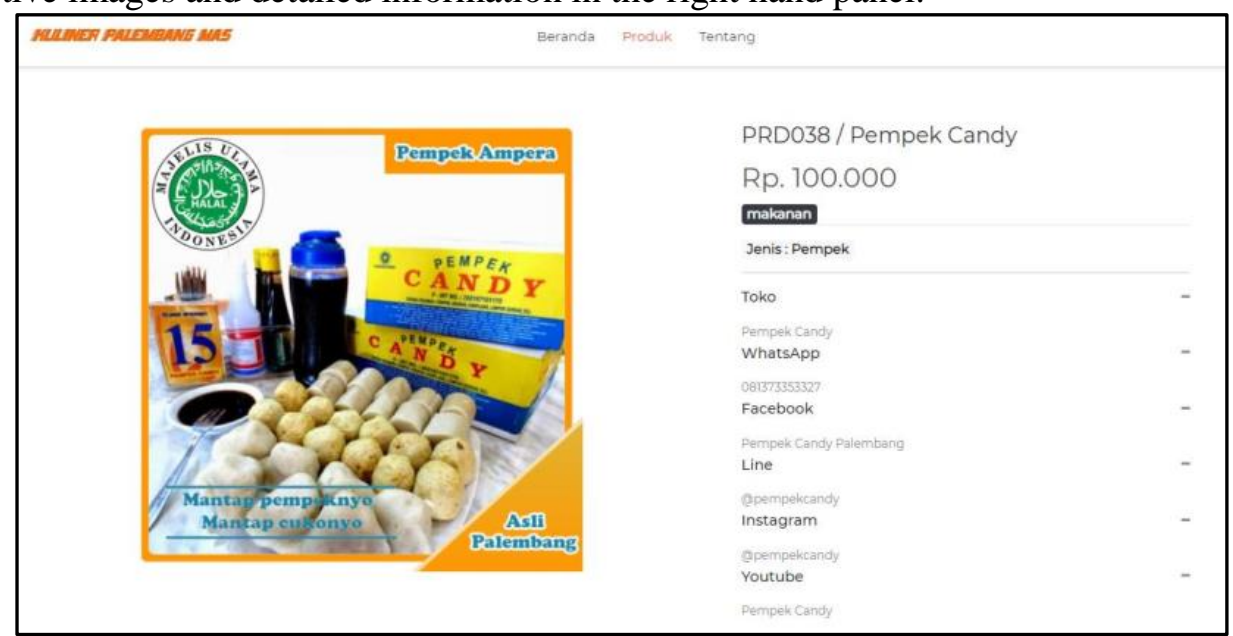

Figure 7 Product view menu 


\section{CONCLUSION}

This research resulted in prototype website culinary information system typical of Palembang. On the website, every business owner who wants to promote his culinary business can have a register. After the registration is approved by the admin, the SMEs can easily and freely promote their products. This website also focuses on promoting the culinary specialties of Palembang in the form of pempek, kemplang, and various cakes typical of Palembang. Website is also equipped with a number of social media from culinary businesses (Facebook, WhatsApp, etc.). For further research, it is expected to develop a mobile application that is typical of Palembang culinary promotions equipped with its geographical location.

\section{REFERENCES}

[1] L. A. Abdillah, "Analisis Aplikasi Mobile Transportasi Online Menggunakan User Experience Questionnaire pada Era Milenial dan Z," JSINBIS (Jurnal Sist. Inf. Bisnis), vol. 9, no. 2, pp. 204-211, Nov. 2019.

[2] J. Clement, "Most popular social networks worldwide as of January 2020, ranked by number of active users (in millions)," 2020. [Online]. Available: https://www.statista.com/statistics/272014/global-social-networks-ranked-by-number-ofusers/. [Accessed: 09-Mar-2020].

[3] D. R. Rahadi and L. A. Abdillah, "The utilization of social networking as promotion media (Case study: Handicraft business in Palembang)," in Seminar Nasional Sistem Informasi Indonesia (SESINDO2013), 2013.

[4] A. Trihandayani and L. A. Abdillah, "Analisis Penerimaan Pengguna dalam Memanfaatkan Media Sosial Terhadap Usaha Kecil Menengah Menggunakan Metode Technology Acceptance Model (TAM)," in Bina Darma Conference Computer Science (BDCCS2019), 2019, pp. 2214-2221.

[5] WHO, "Naming the coronavirus disease (COVID-19) and the virus that causes it," 2020. [Online]. Available: https://www.who.int/emergencies/diseases/novel-coronavirus2019/technical-guidance/naming-the-coronavirus-disease-(covid-2019)-and-the-virus-thatcauses-it. [Accessed: 14-Apr-2020].

[6] A. E. Gorbalenya et al., "The species Severe acute respiratory syndrome-related coronavirus: classifying 2019-nCoV and naming it SARS-CoV-2," Nat. Microbiol., vol. 5, no. March, 2020.

[7] L. A. Abdillah, "Stigma Terhadap Orang Positif COVID-19," in Pandemik COVID-19: Antara Persoalan dan Refleksi di Indonesia, Medan: Yayasan Kita Menulis, 2020.

[8] A. M. Kaplan and M. Haenlein, "Users of the world, unite! The challenges and opportunities of Social Media," Bus. Horiz., vol. 53, no. 1, pp. 59-68, 2010.

[9] L. A. Abdillah, "An Overview of Indonesian Fintech Application," 1st Int. Conf. Commun. Inf. Technol. Youth Study, pp. 8-16, 2019.

[10] R. S. Pressman and D. B. Lowe, Web engineering. New York, USA: McGraw-Hill Higher Education, 2009.

[11] R. Thackeray, B. L. Neiger, C. L. Hanson, and J. F. Mckenzie, "Enhancing Promotional Strategies Within Social Marketing Programs: Use of Web 2.0 Social Media," Health Promot. Pract., vol. 9, no. 4, pp. 338-343, 2008.

[12] W. G. Mangold and D. J. Faulds, "Social media: The new hybrid element of the promotion mix," Bus. Horiz., vol. 52, no. 4, pp. 357-365, 2009. 
[13] C. Chittithaworn, A. Islam, T. Keawchana, and D. H. M. Yusuf, "Factors affecting business success of small \& medium enterprises (SMEs) in Thailand," Asian Soc. Sci., vol. 7, no. 5, pp. 180-190, 2011.

[14] G. Barovih and Nurussama, "Penerapan E-Commerce dan Inovasi Kemasan untuk Produsen Pia Kota Palembang," in Prosiding Seminar Nasional Hasil Litbangyasa Industri, 2018, pp. $118-128$.

[15] A. Tenggono, "Aplikasi Pencarian Lokasi Kuliner Empek-Empek di Kota Palembang 'Pempek Finder," in Seminar Nasional Informatika (SNIf2015), 2015, pp. 201-206.

[16] Presiden Republik Indonesia, "UU No. 20 Tahun 2008," Undang-Undang Republik Indonesia Nomor 20 Tahun 2008 Tentang Usaha Mikro, Kecil, dan Menengah. Sekretariat Negara Republik Indonesia, Jakarta, 2008.

[17] L. A. Abdillah, Sistem Basis Data Lanjut I: Membangun Sistem Basis Data. Palembang: Pusat Penerbitan dan Percetakan Universitas Bina Darma, 2003.

[18] L. A. Abdillah, "Systems Analysis and Design," Computer Science for Education, 2016. [Online]. Available: http://blog.binadarma.ac.id/mleonaa/teaching/systems-analysis-anddesign/.

[19] A. Dennis, B. H. Wixom, and D. Tegarden, Systems Analysis \& Design: An Object-Oriented Approach with UML, 5th ed. Hoboken, New Jersey, USA: John Wiley \& Sons, Inc., 2015.

[20] K. E. Kendall and J. E. Kendall, Systems Analysis and Design, 9th ed. Upper Saddle River, New Jersey, USA: Pearson Education, Inc., 2014.

[21] R. Elmasri and S. B. Navathe, Fundamentals of Database Systems, 6th ed. Boston,Massachusetts, USA: Pearson Education, Inc. (Addison-Wesley), 2011.

[22] C. Coronel and S. Morris, Database Systems: Design, Implementation, and Management. Boston, MA, USA: Cengage Learning.

[23] D. Manulang, L. A. Abdillah, and Kurniawan, "Sistem Informasi Penjualan Online (ECommerce) Menggunakan CMS Wordpress pada Toko Soraya Shop dengan Menerapkan Metode RAD," in Seminar Hasil Penelitian Sistem Informasi dan Teknik Inormatika ke-3 (SHaP-SITI2017), 2017, pp. 7-12.

[24] L. A. Abdillah, "Students learning center strategy based on e-learning and blogs," in Seminar Nasional Sains dan Teknologi (SNST) ke-4 Tahun 2013, 2013, p. F3. 15-20 PDF.

[25] Fikri, L. A. Abdillah, and E. Apriyani, "Perancangan Teknologi Cloud Untuk Penjualan Online Kain Songket Palembang," in Seminar Nasional Sistem Informasi Indonesia ke-8 (SESINDO2015), 2015. 